\title{
Contributions of visual management to trend analysis
}

\section{Alessandro Mateus Felippe}

Master, Universidade do Estado de Santa Catarina / alessandro@fiodameada.me Orcid: 0000-0001-6856-3991 / lattes

\section{Sandra Regina Rech}

PhD, Universidade do Estado de Santa Catarina / sandra.rech@udesc.br Orcid: 0000-0002-0062-6914/ lattes

\section{Icléia Silveira}

PhD, Universidade do Estado de Santa Catarina / icleiasilveira@gmail.com Orcid: 0000-0003-4493-9768/ lattes

Sent: 07/31/2020 // Accepted: 12/09/2020 


\title{
Contributions of visual management to trend analysis
}

\begin{abstract}
This text, an integral fragment of the ongoing master's research, has as main theme the theoretical-conceptual approach between trends and visual management, aiming to qualify the trend analysis method proposed by Dragt (2017) from principles and tools of visual management. In methodological terms, the article is designed in the moments of conceptualizing important terms through the Bibliographic Review, as well as the collection, reduction, categorization and interpretation of data via Qualitative Data Analysis. Furthermore, the text is classified as being of a basic, qualitative nature and with descriptive objectives. The results achieved demonstrate that the principles and tools of visual management add different advantages to the process, such as innovation, agility and encouraging the collaboration of the participants of those involved in the analysis of trends.
\end{abstract}

Keywords: trend analysis. Visual management. Method. 


\title{
Contributos da gestão visual para análise de tendências
}

\begin{abstract}
RESUMO
Este texto, fragmento integrante da investigação de mestrado em andamento, possui como temática central a aproximação teórica-conceitual entre tendências e gestão visual, objetivando qualificar o método de análise de tendências proposto por Dragt (2017) a partir de princípios e ferramentas da gestão visual. Em termos metodológicos, o artigo se desenha nos momentos de conceituar termos importantes por meio da Revisão Bibliográfica, bem como a coleta, redução, categorização e interpretação de dados via Análise Qualitativa de Dados. Ademais, classifica-se o texto como sendo de natureza básica, qualitativa e com objetivos descritivos. Os resultados alcançados demonstram que os princípios e as ferramentas da gestão visual agregam diferentes vantagens ao processo, tais como inovação, agilidade e incentivo a colaboração dos participantes do envolvidos na análise de tendências.
\end{abstract}

Palavras-chave: análise de tendências. gestão visual. método. 


\title{
Contribuciones de la gestión visual al análisis de tendencias
}

\begin{abstract}
RESUMEN
Este texto, fragmento integral de la investigación del máster en curso, tiene como tema central el abordaje teóricoconceptual entre tendencias y gestión visual, con el objetivo de calificar el método de análisis de tendencias propuesto por Dragt (2017) a partir de principios y herramientas de gestión visual. . En términos metodológicos, el artículo se diseña en los momentos de conceptualización de términos importantes a través de la Revisión Bibliográfica, así como la recolección, reducción, categorización e interpretación de datos vía Análisis Cualitativo de Datos. Además, el texto se clasifica como de carácter básico, cualitativo y con objetivos descriptivos. Los resultados obtenidos demuestran que los principios y herramientas de la gestión visual añaden diferentes ventajas al proceso, como la innovación, la agilidad y el fomento de la colaboración de los participantes de los implicados en el análisis de tendencias.
\end{abstract}

Palabras: análisis de tendencias. manejo visual. método. 


\section{INTRODUCTION}

The so-called Information Society (CASTELLS, 2009), a concept postulated at the end of the 20th century, understands that social relations are built from the exchange of information, and these data are extremely important for the development of society. In this way, information has a leading role in cultural, political, educational, economic interactions, among others, since it has different origins, purposes and influences the ability to change and influence different logics of producing and consuming goods.

Therefore, the areas of knowledge that aim to collect, analyze and interpret social complexity have a crucial role in understanding human behavior, cultural manifestations and paradoxical logic of the final consumer, either to understand consumer desires in general, or for the prototyping of specific solutions. This challenge becomes more complex as the amount of information produced, and which needs to be analyzed, increases exponentially, as emphasized by Luciana Stein, director of a reference company in the area of trend analysis in South and Central America (TRENDWATCHING, 2020).

Considering this metaphorically liquid context (BAUMAN, 2011) in which there is a constant emergence of information, this text problematizes the analysis of trends and how this field of knowledge can be qualified through visual approaches, supported by advantages such as: viewing a large amount of information, make a dynamic, innovative project with great incentive to engage / participate in people determined and generate a continuous flow of work and results. In other words, the problem in this article is: how to qualify the model proposed by Dragt (2017) for trend analysis based on principles and tools of visual management? 


\section{METHODOLOGY}

Here, research is classified in scientific terms through the use of methods, techniques and procedures, since the scientific methodology is seen as a means to "discover answers to problems through the use of scientific procedures" as highlighted by Gil (2008, p. 42). In this way, the methodological steps comprise research with a basic purpose, as it aims to "increase and / or generate new knowledge, build theories" without expected practical application (ZAMBERLAN, 2014, p. 93).

From the point of view of approaching the problem, it is classified as qualitative. According to Gil (2008, p. 15), the qualitative approach "considers that there is a dynamic between the real world and the subject", implying an interpretation and construction of meanings based on the data obtained throughout the study. From the point of view of the desired objectives, they are considered descriptive, since this type "aims to describe the relationships between variables" (SILVEIRA, 2018, p. 17) working with the report of some fact or phenomenon.

Then, for data collection, it used the methodology of Bibliographic Review, presenting a theoretical and conceptual articulation between the various authors in order to answer the intention proposed in the introduction. According to Lakatos and Marconi (2017), this methodology allows contacting the published theoretical framework, whether in monographs, theses, books or even in audiovisual materials, that is, through the review of the bibliography, one can understand what has already been done. researched, main conclusions and opportunities for new approaches on the same subject. For the analysis of the collected data, the Qualitative Data Analysis methodology was used, being 
defined as a process articulated with the steps of data reduction, categorization and interpretation (GIL, 2017; SILVEIRA, 2018; GIL, 2008).

In a methodological design, after defining the concepts of trend analysis and visual management, a synthesis of advantages, principles and visual management tools is presented in the data reduction and categorization session; subsequently, the data were applied and interpreted in the trend analysis method proposed by Dragt (2017) in the data interpretation session, resulting in the qualification that visual management can bring to the trend analysis presented in Chart 5.

Finally, this text is configured as a partial result of the ongoing master's research, showing theoretical fragments of the second chapter and syntheses of methods for analyzing trends and advantages, principles and tools of visual management that make up the fourth chapter of that dissertation ${ }^{1}$.

\section{CONCEPTS}

\subsection{Trend analysis}

The word trend is polysemic and is understood as a synonym for movement, novelty, anticipation, uncertainty, society photography and being in vogue in a certain space and time (CAMPOS; WOLF, 2018; ERNER, 2015; DRAGT, 2017; RAYMOND, 2010; RECH, 2013; RECH; GOMES, 2016). In this sense, it can be seen as "phenomena that provide tangible evidence of social, relational and cultural changes" and have an "intricate life cycle, in constant evolution" (RECH, 2013, p. 109). In this sense, from a taxonomy, the trends can be divided into two main categories, presented in Table 1: 
Table 1: Classification of trends based on differentiation parameters

\begin{tabular}{|l|l|l|}
\hline & Macro-trends & Micro trends \\
\hline Adoption & Wide & Restricted \\
\hline Belonging & General & Particular \\
\hline Duration & Long & Brief \\
\hline Impact & Substantial & Subtle \\
\hline Diffusion & More slowly & Faster \\
\hline Predictability & Difficult & Easy \\
\hline Sociocultural basis & Evident & Hidden \\
\hline \multicolumn{2}{|c|}{ Source: Campos (2020). }
\end{tabular}

With a historical and also contemporary bias, "a trend (in the general sense of the word) is the inclination predisposed to something, someone or some situation that is likely to happen in the near future". In other words, it is a paradigm that directs society's gaze, thinking and attitudes towards a certain direction, and may or may not materialize. In a complementary way, the word trend addresses otherness, generating an atmosphere of "[a] finite; that is, a situation that will be achieved; and [b] futurology; that is, suggesting that the situation will happen in the future "(CAMPOS; WOLF, 2018, p. 19).

Trend analysis is defined as a set of methods, procedures and tools for identifying, understanding and disseminating trends. The authors Maioli and Presotto (2012, p. 24) state that in order to analyze trends "we must always approach different methodologies in a multidisciplinary way". Thus, it uses ethnographic studies, participant observation verifying innovations driven by trendsetters (defined as promoters of trends), fieldwork instruments (qualitative and quantitative) and secondary research based on semiotics.

Rech and Silveira (2017, p. 4) point out that the trend analysis is based on a transdisciplinary logic, since as an area, "procedures and concepts from other disciplines are mixed 
and incorporate fluctuations in behaviors and consumption parameters" allowing the observation of repetition patterns that can give evidence of the emergence and architecture of trends.

In this way, the focus of trend analysis is not guided by signals from a specific segment, but all those that can generate innovation, cause changes and design scenarios about the future are mixed. Considering its characteristics and its respective research area, it is understood that the use of trends by product development professionals from various segments presupposes insights, generating competitiveness insofar as these can be understood as a photograph of the reality of society, in which it is possible to capture / intuit / deduce what is happening, what ideas are giving movement to certain behaviors in a space-time frame (RECH; GOMES, 2016).

Not only that, but also "a trend is a social process that suggests a behavioral change based on emerging mentalities [...] revealing important and solid clues for generating innovation" (RECH; GOMES, 2016, p. 4). Therefore, "not looking" for trends can mean ignoring clues, signs and manifestations of behavior patterns, new technologies and different desires on the part of consumers.

In addition, it is extremely important to use the results generated from the identification of certain trends as a source of information and inspiration for product design, since trends are "focal points of desire, through which individuals very different from each other. Others and without common agreement, the same desires are discovered "(ERNER, 2015, p. 9).

In this sense, it is understood that the trend research can be seen as a project, since it is configured as an effort in a certain time and space with the aim of developing a product / 
service / good / result, having a beginning and a beginning. And previously established, considering the theory supported by the authors seen until then. Therefore, in order to carry out a methodological analysis of trends, it is necessary to collect, process, organize, systematize and interpret much information, reaching the mapping of a future, of a collective mentality that influences behavior, multiple ways of subjects interacting with the world and that makes a register of the society; in other words, from the management of a lot of information from macro trends, market behavior and reference sectors, one can arrive at the result of mapping a trend and make strategic use of this information (CAMPOS; RECH, 2016).

\subsection{Visual management}

It is a fact that in the last few decades a large amount of information has been produced, in qualitative and quantitative terms, when compared to the entire history of mankind. This was feasible from the improvement of technology (production and storage), such as the internet, being feasible to break, in a metaphorical sense, the barriers of time and space. That is, today you can access information from another country (another context / physical space) through research platforms or watch a video lesson from a design school from another continent produced five years ago (another time), catalyzing a new process of time and space in the production and consumption of information (CASTELLS, 2009).

In this sense, it is understood that information has great value for different purposes and access to them is increasingly democratic. These, considering infinite possibilities, can be used to innovate a product, recognize the rise of a new market for the marketing sector, understand disruptive consumption 
behaviors, give educational opportunities to social groups lacking this access and, in a specific sense of research, develop design, communication and consumer goods projects. And, in order to live up to this very relevant diagnosis, it is crucial to manage this information in the school, organizational, business, entertainment, cultural context, etc.

Teixeira (2018) starts from this input to reflect assertive and strategic ways of carrying out information management within projects in organizations, as the objective is to promote a democratic, dynamic and methodological view of the processes developed from information. "By making processes more visual, we facilitate understanding and decision-making; this tends to make projects leaner "(TEIXEIRA, 2018, p. 23) and encouraging processes of innovation and generation of insights.

Therefore, it is understood that the processes of encoding and decoding human information can be more fluid when making it visual, with repetitions of patterns and methodological structures that provide greater usability. As reflected by Sibbet (2013, apud TEIXEIRA, 2018, p. 26), the main benefit of performing visual management is that "designers, data analysts, decision makers and other interested parties can focus their cognitive and perceptive attentions, in the form of the visualization of information ", that is, the benefits are clear when the organization of much information becomes visual.

Another reference that contributes to the understanding of the concept of visual management is Galsworth (2005), from the perspective of establishing an organized workspace that eliminates information deficits, that is, all data and inputs are easily located and processed in an almost intuitive by stakeholders. Teixeira (2015, p. 59) deals with the visual management of projects, having by definition a "set of 
actions, tools and models that aims to promote greater visualization of the project development process". In other words, it is added to this visual logic the elaboration of projects in business terms in the development of products, services, solutions, design, among others.

The lack of structuring of models, processes, protocols during the development of a project can result in "communication failures, interpretation errors, frustrations and disputes, which hinder the team's evolution and productivity" (TEIXEIRA, 2018, p. 25 ). In other words, planning the management of tasks, responsible persons, important deadlines, among other issues that involve the development of a project, generates greater drowsiness, speed and impulses for innovation.

\section{ANALYSIS AND DISCUSSION}

\subsection{Data reduction and categorization - advantages, guidelines and visual management tools}

Thus, the advantages of using the visual management approach are presented based on the research conducted by Tezel et al. (2009), which are:

Table 2: Advantages of visual management

\begin{tabular}{|l|l|}
\hline Transparency & $\begin{array}{l}\text { It allows democratic access to information by all professionals } \\
\text { involved in the process. }\end{array}$ \\
\hline subject & Encourages stakeholders to keep procedures organized \\
\hline Continuous improvement & $\begin{array}{l}\text { Enables you to view the process as a whole on a frequent } \\
\text { basis and qualify whatever is necessary }\end{array}$ \\
\hline Work facilitation & Makes the execution of demands more dynamic and assertive \\
\hline $\begin{array}{l}\text { "On-the-job training" / } \\
\text { in-service training, in free } \\
\text { translation }\end{array}$ & Facilitates learning through visual experience \\
\hline $\begin{array}{l}\text { Creation and shared } \\
\text { participation }\end{array}$ & $\begin{array}{l}\text { Engagement of participants based on the physical } \\
\text { materialization of solutions }\end{array}$ \\
\hline
\end{tabular}




\begin{tabular}{|l|l|}
\hline Fact management & Use of pragmatic and specific data throughout the process \\
\hline Simplification & $\begin{array}{l}\text { Redução e fragmentação de informações/protocolos/processos } \\
\text { completos }\end{array}$ \\
\hline Unification & $\begin{array}{l}\text { Encourages the construction of a more empathetic and } \\
\text { organized work environment }\end{array}$ \\
\hline
\end{tabular}

Source: Tezel et al. (2009).

In addition, Teixeira (2018) underlines principles for proposing the visual management of a project, which will be valid for the analysis and interpretation of data later, detailed below:

Table 3: Principles for creating a visual project management model

\begin{tabular}{|l|l|}
\hline Principles & Application tips \\
\hline $\begin{array}{l}\text { Visualization as a process } \\
\text { guiding axis }\end{array}$ & $\begin{array}{l}\text { Develop a set of methods and tools with a focus on } \\
\text { visualization. }\end{array}$ \\
\hline $\begin{array}{l}\text { Establish and use a } \\
\text { reference model }\end{array}$ & Standardize the use of a single project development model. \\
\hline $\begin{array}{l}\text { Promote information } \\
\text { visualization }\end{array}$ & $\begin{array}{l}\text { Use visual panels in design environments; create delivery } \\
\text { guidance sheets. }\end{array}$ \\
\hline Drive systemically & Indicate incoming, outgoing and transformation flows. \\
\hline Focus on value & Determine what is value to stakeholders. \\
\hline Generate streaming & $\begin{array}{l}\text { Promote a continuous flow of project development, mainly } \\
\text { through the flow of information }\end{array}$ \\
\hline $\begin{array}{l}\text { Promote collective } \\
\text { participation }\end{array}$ & $\begin{array}{l}\text { Involve employees by providing them with access to } \\
\text { information. }\end{array}$ \\
\hline
\end{tabular}

Source: Adapted from Teixeira (2018).

In addition, the lack of structuring of models, processes, protocols during the development of a project can result in "communication failures, errors of interpretation, frustrations and disputes, which hinder the evolution and productivity of the team" (TEIXEIRA, 2018, p. 25). In this sense, from different authors and theories, a summary table of visual tools is presented in Chart 4 : 
Quadro 4: Síntese de ferramentas visuais

\begin{tabular}{|c|c|c|}
\hline Tool & Description and function & $\begin{array}{l}\text { Reference } \\
\text { authors }\end{array}$ \\
\hline $\begin{array}{l}\text { A3 } \\
\text { Storyboard }\end{array}$ & $\begin{array}{l}\text { Tool that came up with Lean / Lean Thinking proposals } \\
\text { for the factory / manufacturing floor; A3 reports have } \\
\text { evolved to become a standard model for problem solving; } \\
\text { the idea is that these panels are fixed in the production } \\
\text { environment so that everyone has access. }\end{array}$ & Dennis (2010) \\
\hline $\begin{array}{l}\text { Business } \\
\text { Model } \\
\text { Generation - } \\
\text { BMG } \\
\text { (Canvas) }\end{array}$ & $\begin{array}{l}\text { It is a tool for business modeling; its success is due to the } \\
\text { assumption that visualizing the main elements in a single } \\
\text { plan makes it easier to perceive the relationship between } \\
\text { the parties in a global way. }\end{array}$ & $\begin{array}{l}\text { Osterwalder, } \\
\text { Pigneur } \\
\text { (2011) }\end{array}$ \\
\hline $\begin{array}{l}\text { Scrapbook } \\
\text { Cards }\end{array}$ & $\begin{array}{l}\text { It is a tool that suggests the use of quick notes containing } \\
\text { the name of the task / process to be performed, the } \\
\text { person in charge, expected delivery date, among other } \\
\text { important information. }\end{array}$ & $\begin{array}{l}\text { Amaral et al. } \\
(2011)\end{array}$ \\
\hline $\begin{array}{l}\text { Spaces for } \\
\text { accessing } \\
\text { information }\end{array}$ & $\begin{array}{l}\text { It is the construction of spaces that allow the visualization } \\
\text { of different information (such as the coffee room, for } \\
\text { example); this was feasible after mapping different } \\
\text { companies that have this practice. }\end{array}$ & $\begin{array}{l}\text { Eppler, Platts } \\
\text { (2009) }\end{array}$ \\
\hline Lean Chips & $\begin{array}{l}\text { It is a tool that brings relevant information on budget for } \\
\text { those involved in the execution of the project. }\end{array}$ & $\begin{array}{l}\text { Lean } \\
\text { Enterprise } \\
\text { Institute } \\
(2007)\end{array}$ \\
\hline $\begin{array}{l}\text { Photo-diary / } \\
\text { photo-diary }\end{array}$ & $\begin{array}{l}\text { Tool that allows the continuous recording of a } \\
\text { phenomenon to be studied, resulting in photographs that } \\
\text { have relationships with the user with subjective contents; } \\
\text { it can also be used in initial consumer research, } \\
\text { inspirational records, modeling tests or usability } \\
\text { experiments. }\end{array}$ & $\begin{array}{l}\text { Sanches } \\
(2017) ; \text { Bona } \\
(2019)\end{array}$ \\
\hline Kanban & $\begin{array}{l}\text { It is a device that provides information (part name, } \\
\text { codes, suppliers, storage, etc.) and instructions / status } \\
\text { (to do, doing, done, to do, in development, finished) } \\
\text { important for understanding a specific stage of the } \\
\text { project; the term means signs or signboard in Japanese. }\end{array}$ & $\begin{array}{l}\text { Teixeira, } \\
\text { Schoenardie, } \\
\text { Merino (2011) }\end{array}$ \\
\hline $\begin{array}{l}\text { Mood Chart / } \\
\text { Mood Board }\end{array}$ & $\begin{array}{l}\text { Tool that assists in the visual representation of concepts } \\
\text { from the collage (physical or digital) of different images, } \\
\text { ideally symbolizing the image universe of the project or } \\
\text { solution. }\end{array}$ & Burdek (2006) \\
\hline $\begin{array}{l}\text { Audience } \\
\text { lifestyle / } \\
\text { lifestyle } \\
\text { panel }\end{array}$ & $\begin{array}{l}\text { Panel with the objective of presenting elements that } \\
\text { present the lifestyle profile of the future consumer of the } \\
\text { planned solution; the selection of images involves } \\
\text { personal, social values, products used, among other } \\
\text { information that contribute to the understanding of the } \\
\text { target audience; in addition to the static format, it can be } \\
\text { presented in video format. }\end{array}$ & Baxter (2011) \\
\hline $\begin{array}{l}\text { Semantic } \\
\text { Panel }\end{array}$ & $\begin{array}{l}\text { Tool that gathers images, expressions, clippings, textures } \\
\text { and communicates through visual metaphors; can be } \\
\text { used as an expression of the product or solution and is } \\
\text { developed by means of collage (physical or digital). }\end{array}$ & $\begin{array}{l}\text { Sanches } \\
(2017)\end{array}$ \\
\hline $\begin{array}{l}\text { Project } \\
\text { Model }\end{array}$ & $\begin{array}{l}\text { It is a tool inspired by Canvas and allows a visual } \\
\text { understanding of project concepts, team engagement and }\end{array}$ & $\begin{array}{l}\text { Finocchio } \\
\text { Júnior (2013) }\end{array}$ \\
\hline
\end{tabular}




\begin{tabular}{|l|l|l|}
\hline Canvas & $\begin{array}{l}\text { decision-making; this contributes to the understanding } \\
\text { that a panel can assist in a planned and visual way the } \\
\text { overall planning of the project. }\end{array}$ & \\
\hline Sketchbook) & $\begin{array}{l}\text { Tool that allows a physical space to record learning, data, } \\
\text { experimenting with ideas, among other possibilities; can } \\
\text { be materialized in a small notebook for personal use. }\end{array}$ & $\begin{array}{l}\text { Seivewright } \\
\text { (2009) }\end{array}$ \\
\hline $\begin{array}{l}\text { Trend book / } \\
\text { trend report }\end{array}$ & $\begin{array}{l}\text { Instrument for communication, dissemination and } \\
\text { translation of trends; its shape does not follow a regular } \\
\text { pattern and is often adapted according to the trend itself } \\
\text { or the area investigated. }\end{array}$ & $\begin{array}{l}\text { Dragt (2017); } \\
\text { Flores (2019) }\end{array}$ \\
\hline
\end{tabular}

Fonte: Autor (2020)

Finally, it should be noted that there is an inexhaustible source of other visual tools; however, this synthesis proposed to present tools of recurrent use in the area of project / product development and fashion design found in the pertinent literature and which concern the central problematization of the dissertation.

\subsection{Data interpretation - visual management applied to trend analysis}

The trend analysis model, synthesized from the work How to research trends proposed by Dragt (2017), is configured as content of relevance and focus for analysis of this text. In this topic, the structure designed by the author divided into three main phases (scan, analyze and apply) is presented, and then the steps that make up each phase are detailed; later, such steps will be articulated and interpreted with the principles presented in table 3 and the tools detailed in table 4 , through the qualitative data analysis approach (GIL, 2017; 2008).

For Dragt (2017, p. 14), research methods generally seek new knowledge, since they are configured as a "systematic investigation of a given topic, in order to ascertain facts and reach new conclusions". Thus, considering the complexity and interconnectivity of the current world, trend analysis becomes 
a challenge for professionals and companies, since it implies the observation, detailing and constant monitoring of changes in several factors such as technology, economics, politics, society, among others.

Similarly, researcher Buck (2019, p. 110) argues that there are countless possibilities for proposing trend analysis, since "efficient work with trends means more than just the identification of each trend and its use related to products ". Therefore, using trend information to guide organizational decisions is at the same level as the so-called innovation policies and / or corporate business plans focused on innovation. Thus, Buck (2019) presents the following comprehensive possibilities for analyzing trends in the organizational context: (I) Future Strategies; (II) Business Strategies; (III) Portfolio Strategies; (IV) Positioning Strategies; (V) Brand Strategies; (VI) Brand Strategies; (VI) Transfer Strategies; (VII) Target group strategies; (VIII) Organization Strategies; (IX) Cooperation Strategies. Ultimately, alignment in the development of solutions with the values and needs emerging in a given social context is important.

Dragt (2017, p. 14) defines trends as a "direction of changing values and needs that is driven by forces and manifests itself in several ways". That said, during the trend analysis process, it is very important to consider the pastpresent-future triad and its mutual strengths, since society uses the past to guide its future behavior. Finally, the professional who seeks to understand what a certain change in the social sphere means needs to be creative, persistent, have a visual thought, have quick and easy recognition of signs of change and be a good storyteller (RECH; GOMES, 2016). 
Figure 1: Structure for trend analysis

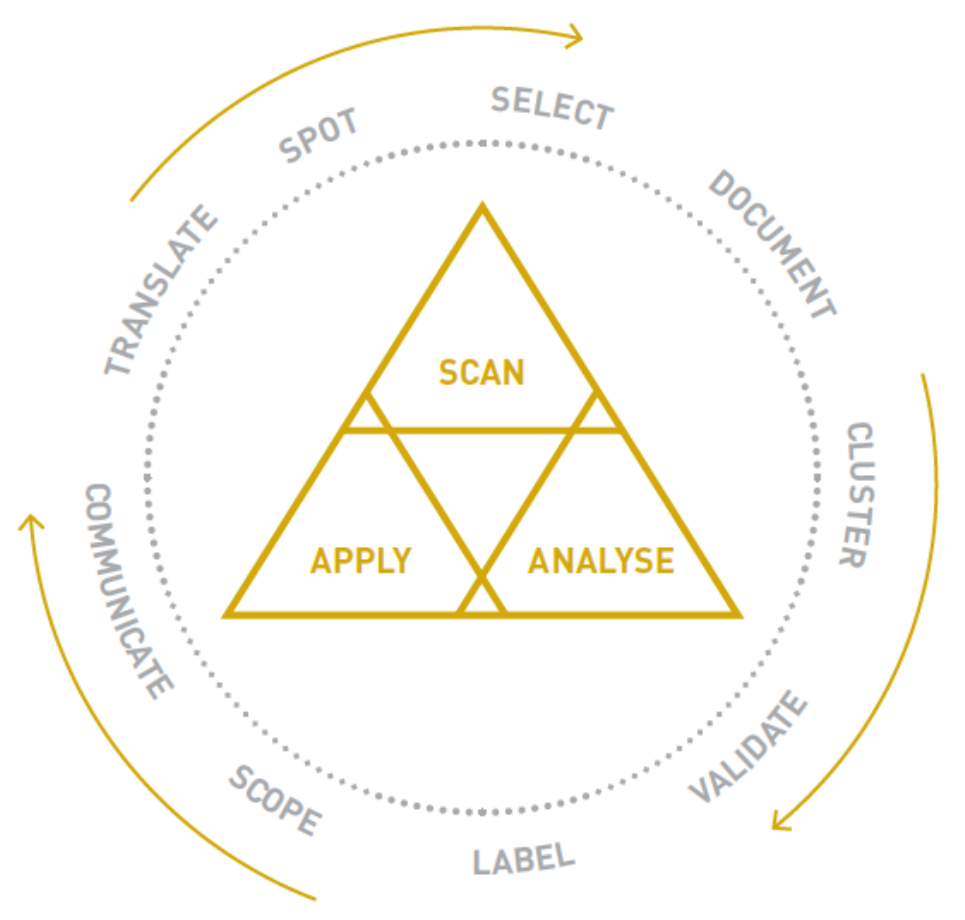

Source: Dragt, 2017.

Objectively, Figure 1 presents the structure of the trend analysis method organized in the scanning, analysis and application phases and subdivided into nine stages, resulting in a circular methodological proposal, that is, it starts at the spot step and ends in the translation, being possible the immediate beginning in the search for new signs of changes in case the researcher perceives the need.

Generally speaking, phase (a) scanning corresponds to the moment of looking carefully at society, mapping and collecting all the changes that are happening; it consists of the steps called spot, select and document; phase (b) analysis seeks to understand, in an interpretative approach, the reason for these changes to happen, their interconnections, relationships, seeking to understand the why and is structured by cluster, validate and label; finally, in the phase named (c) application, after understanding and naming certain trends, it is proposed to validate the trends from practical application to 
specific problems, generating insights, product development and inspiring innovative solutions; the phase consists of steps called scope, communicate and translate.

In view of this, it is understood that the first two phases are in fact researching changes in society to understand and verify emerging trends. The third phase aims at the applicability of the results achieved, resulting in innovation and the solution of specific problems, whether in companies, schools, universities, creative studios, communication agencies or other social spaces that are influenced by technological, behavioral, economic, political changes, environmental...

\section{- Scan}

In this sense, trend analysis begins by checking / scanning signs and clues for changes in society through different perspectives in step 01 called spot, or rather, it seeks manifestations that go against the tradition and conventional thinking of different origins (culture, music, art, technology, events, exhibitions, festivities, on the street ...); at this time, the quantity overlaps the quality of information collected. Here one can think about the use of the visual photo-daily tool in conjunction with the sketchbook as a means of recording the hunting of signs (GLOOR, 2011) that are interpreted as points outside the curve, or even what is happening / being developed in the edge of society (WEBB, 2016) and articulated with the principle of visual management of visualization as the guiding axis of the process.

Step 02, called select, aims to select the most relevant signs of change considering quality and not quantity; selection criteria are also made to better organize the information; for this selection, key questions can contribute: Is the sign innovative? Is it inspiring? Is it easy to understand and communicate it? Is it considered an anomaly? Is this sign true, 
is it reliable? Does it have a creative impact? (DRAGT, 2017; GOMES, COHEN, FLORES, 2018). At this time, you can use the tool lean cards, by adapting them according to the key questions, offering a space with quick and objective answers about that signal. Also, the materials collected in the previous step can be attached using the photo-diary tool; the principle adopted is the generation of continuous flow, since it is possible to constantly update this process at this moment of signal selection.

Step 03, called document, corresponds to the moment of knowing the context of the selected signals in a deeper way; some questions can facilitate: What is it? How does it work? What was the first time this came / came / happened? Who is the creator? Can this be related to some aspect of quality of life? It is also important to establish sources for future contacts about the information. For this reason, it is possible to implement the tool spaces for access to information, since it is possible to expand the records made in the previous step, offering a wide view of what was collected; furthermore, the principle indicated in the structuring of that moment is, again, visualization as the guiding axis.

\section{- Analyze}

Step 04, called a cluster, aims to group the signals collected by categories that manifest the same needs and values through the question "why does this happen?", That is, trying to fit different pieces of a big puzzle to understand the manifestations of emerging trends, since "a trend is, therefore, a pattern, a form" (FLORES, 2019, p. 85); here the collaboration of other researchers in the organization of information becomes important, overlapping personal opinions, through discussion and reflection (DRAGT, 2017; in this step, the semantic panel tool can be used for the possibility of overlapping and handling different information, 
in a procedural and not definitive logic, the principle of promoting collective participation is present, encouraging collaborative work.

Step 05, validate, deepens the collection of information about the collected signals, seeking consistency, relevance, emergence and validation; thus, the maximum amount of information about the data collected is collected in order to elaborate a coherent and singular history; some questions can be asked: Why is this happening right now? What is the specific change in value or need that this signal causes? Who started it and who is spreading it? Are there any consequences of this for people's future quality of life? (DRAGT, 2017). In addition to the expansion of the records in the lean forms, the use of the lifestyle panel and the adoption of the A3 storyboard tool are also suggested, as they allow the coherent narration of the facts that are being interpreted. The principle adopted at that time is the focus on value, since it is necessary to validate the important values and needs for understanding the trend, from a qualitative perspective for the trend analysis process (RECH, CARDIM, 2016).

Step 06, label, proposes to name - verbally and visually the researched trend, through the ability to tell stories (that makes sense and causes a positive impact), establishing a trend name and a trend image; the challenge is to create a name that reflects all the complexity, connection and breadth of a trend; for the visual sphere, it is important to select an image that is worth a thousand words to translate all the sensations, feelings, values and needs of the trend; it is suggested, to collaborate with this step, the adoption of mood board tools, semantic panel and lifestyle panel, since they make it possible to summarize visually and verbally all relevant information for understanding the trend and building the trend image and trend name; the principle for choosing 
the tools is the establishment and use of a reference model, as it structures a strategic way for the step of naming the trend.

\section{- Apply}

In the last phase, step 07 called scope, aims to generate insights from the prospected trends, having different objectives as a contribution to solving specific problems for organizations, professionals, researchers and students; in other words, here is the time to understand how to use trends for a challenge. In addition, in this step, monitoring is carried out in search of new changes in society that corroborate, adapt or qualify the investigated trend. In this case, you can make use of the canvas and project model canvas tools as they allow for rapid prototyping of solutions, the design of business models and the quick decision-making; also, it is suggested the introduction of kanban tools and scrap cards, as they allow the visualization of the general status of each stage of the process. In addition to the use of a reference model in the choice of tools, the promotion of collective participation also materializes as a principle while everyone can collaborate in this design of solutions.

Step 08, communicate, seeks to communicate the main results verified in the trend analysis, considering the specific characteristics of the challenge to be solved, briefing or public to whom this information is intended. Therefore, it becomes relevant to define the balance between what you want to say and what the audience (client, contracting agency, school ...) wants to hear. Therefore, it is relevant to align how the trend's story will be told: text, image, video, workshop, presentation, among other possibilities. Here, it is suggested to rescue all the tools used so far, extracting the elements that deserve to be highlighted for the consistency of the story told and 
inserted in the trend book; the principle verified in this step is the visualization of the pertinent information.

Finally, step 09, translate, promotes the translation / diffusion of the trend diagnosed with other people, seeking to converge, diverge and qualify ideas for a better understanding of the future, driving the first steps of changes and innovations. Through new values and needs, it is possible to co-create solutions with the customer, be it a product, service, advertising campaign, event or even positioning / market differential for a new brand. Here we suggest the adoption of space tools for access to information and sketchbook, as this allows collaboration and exchange of ideas between participants and the former can be used to record new perceptions. The principles applied here concern the focus on value, collective participation and visualization as the guiding principle of the process.

However, as found in the bibliography, when choosing to manage a project based on visual management, this requires an understanding of the specific demands of each project; here we sought to present a brief theoretical-conceptual reflection of the contributions of this approach to the analysis of trends, from the study of the method proposed by Dragt (2017) with three main moments: the scanning, analysis and application of trend information. In addition, as already noted, this text is configured as an integral part of partial results of the ongoing master's research.

Table 5: Application of visual management in trend analysis

\begin{tabular}{|l|l|l|l|}
\hline Phase & Step & Principle adopted & Suggested tool \\
\hline scanning & spot & $\begin{array}{l}\text { visualization as a process } \\
\text { guiding axis }\end{array}$ & $\begin{array}{l}\text { photo-diary and } \\
\text { sketchbook }\end{array}$ \\
\cline { 2 - 4 } & select & continuous flow generation & lean and photo-diary cards \\
\cline { 2 - 4 } & document & $\begin{array}{l}\text { visualization as a driving } \\
\text { axis }\end{array}$ & $\begin{array}{l}\text { spaces for access to } \\
\text { information }\end{array}$ \\
\hline analyze & cluster & collective participation & semantic panel \\
\cline { 2 - 4 } & validate & value generation & lifestyle panel and A3 \\
\hline
\end{tabular}




\begin{tabular}{|l|l|l|l|}
\hline & & storyboard \\
\cline { 2 - 4 } & label & $\begin{array}{l}\text { establishment and use of a } \\
\text { reference model }\end{array}$ & $\begin{array}{l}\text { moodboard, semantic } \\
\text { panel and lifestyle panel }\end{array}$ \\
\hline application & scope & $\begin{array}{l}\text { establishment and use of a } \\
\text { reference model and } \\
\text { collective participation }\end{array}$ & $\begin{array}{l}\text { Canvas, project model } \\
\text { canvas, kanban and } \\
\text { scrapbook cards }\end{array}$ \\
\cline { 2 - 4 } & communicate & $\begin{array}{l}\text { Promotion of information } \\
\text { visualization }\end{array}$ & trendbook \\
\cline { 2 - 4 } & translate & $\begin{array}{l}\text { focus on value, collective } \\
\text { participation and } \\
\text { visualization as the guiding } \\
\text { axis of the process }\end{array}$ & $\begin{array}{l}\text { spaces for access to } \\
\text { information and } \\
\text { sketchbook }\end{array}$ \\
\hline
\end{tabular}

Source: the author (2020).

Ultimately, this analysis ends with table 5, summarizing the main results achieved through the theoretical-conceptual articulation of the phases and steps of the trend analysis model, together with the principle adopted and the suggested tool, originating from management visual.

\section{FINAL CONSIDERATIONS}

As a guideline for final considerations, it is first pointed out that it is important to understand the methods of analyzing trends as projects; therefore, they can be understood as viable projects to be managed visually. Secondly, it is confirmed that this type of investigation requires constant dedication from the professionals involved in capturing, organizing, systematizing, interpreting and using information; in other words, it is crucial to strategically plan the trend analysis process to achieve effective results. Therefore, the importance of using visual management principles and tools is highlighted, as they offer resources for innovation, structuring workflows and encouraging the participation / drenching of the professionals involved.

As a third point, it is emphasized that the general objective of qualifying the model proposed by Dragt (2017) for 
analyzing trends with principles and tools of visual management was achieved and materialized in Table 5, through the analytical approach of qualitative data, articulating the nine steps of the trend analysis method with visual management principles and tools reduced and categorized from the congruent literature. Finally, as a fourth point, it should be noted that this text is configured as a partial result of Chapter IV of the ongoing master's research and is not seen as a definitive result, but an ongoing discussion about trend analysis and visual management.

\section{Notes}

1 Dissertation in qualifying progress at the Graduate Program in Clothing Design and Fashion at the Universidade do Estado de Santa Catarina with the title Conceptual model of trend analysis based on visual management projects for the Fashion Lab - Coletivo Criativo in Blumenau/SC.

\section{REFERENCES}

AMARAL, D. et al. Gerenciamento ágil de projetos: aplicação em produtos inovadores. São Paulo: Saraiva, 2011.

BAXTER, M. Projeto de produto: guia prático para o design de novos produtos. 3. ed. São Paulo: E. Blucher, 2011.

BONA, S. F. Método de Projeto de Coleção em Design de Moda: uma configuração para micro e pequenas empresas. 2019. 136p. Dissertação (mestrado) - Universidade do Estado de Santa Catarina, Centro de Artes, Programa de Pós-Graduação, Florianópolis, 2019.2 Disponível em: https://www.udesc.br/arquivos/ceart/id_cpmenu/6295/Disserta_ o_Sheila_Fernanda_Bona_15816930311845_6295.pdf. Acesso em: 25 jul. 2020.

BUCK, A. Diretrizes para a gestão de tendências: inovação e estética como fundamento para o sucesso profissional/ Alex Buck, Christoph Herrmann, Dirk Lubkovitz. Curitiba: PUCPRESS, 2019.

BURDEK, B. E. Design: história, teoria e prática do design de produtos. São Paulo: E. Blucher, 2006.

CAMPOS, A. Q. Taxonomia dos tipos de tendências: uma proposta concisa. Datjournal Design Art and Technology, v. 5, p. 313328, 2020. Disponível em: https://doi.org/10.29147/dat.v5i2.209. Acesso em: 20 jul. 2020. 
CAMPOS, A. Q; RECH, S. R. Método para pesquisa de tendências: uma revisão do modelo Futuro do Presente. In: ModaPalavra eperiódico. v. 9, n.17, jan-jun, 2016. Disponível em: https://doi.org/10.5965/1982615x09172016027. Acesso em: 12 jul. 2020.

CAMPOS, A. Q.; WOLF, B. O Conceito de Tendência na Moda: significado, histórico, conotação. ModaPalavra e-Periódico. n.6, n.11, p. 11-30, jul-dez. Dossiê Estudos de Tendências e Branding de Moda, 2018. Disponível em: http://www.revistas.udesc.br/index.php/modapalavra/article/view/ 11754. Acesso em: 20 jul. 2020.

CASTELLS, M. A Sociedade em rede. 12. ed. São Paulo: Paz e Terra, 2009.

DENNIS, P.. The remedy: bringing lean thinking out of the factory to transform the entire organization. United States of America: John Wiley \& Sons, Inc., 2010.

DRAGT, E. How to research trends: move beyong trend watching to kickstart innovation. BIS Publishers, 2017.

EPPLER, M.; PLATTS, K.. Visual Strategizing: The Systematic Use of Visualization in the Strategic-Planning Process. Long Range Planning, [s.I], v. 42, n. 1, p. 42-74, 19 jan. 2009. Trimestral. Disponível em: http://www.sciencedirect.com/science/article/pii/S0024630108001 180. Acesso em: 26 jul. 2020.

ERNER, G. Sociologia das Tendências. São Paulo: Editora G. Gili, 2015.

FINOCCHIO JÚNIOR, F. Project Model Canvas: gerenciamento de projetos sem burocracia. Rio de Janeiro: Elsevier, 2013.

FLORES, A. M. M. Jornalismo de inovação: os Estudos de Tendências como ferramenta de pesquisa. 2019. 237p. Tese (doutorado) - Universidade Deral de Santa Catarina, Centro de Comunicação e Expressão, Programa de Pós Graduação em Jornalismo, Florianópolis, 2019. Disponível em: https://readymag.com/Miuxapop/jornalismo/. Acesso em: $13 \mathrm{jul}$. 2020.

GALSWORTH, G. Visual Workplace: visual thinking. Portland: Visual-lean Enterprise Press, 2005.

GIL, A. C. Como elaborar projetos de pesquisa. 6. ed. - São Paulo: Atlas, 2017.

GIL, A. C. Métodos e técnicas de pesquisa social. 5 . ed. São Paulo: Atlas, 2008.

GLOOR, P. A. Coolfarming: turn your great ideas into the big thing. New York, NY, 2011.

GOMES, N. P.; FLORES, A. M. M., COHEN, S. Estudos de Tendências - contributo para uma abordagem de análise e gestão da cultura. In: ModaPalavra e-periódico, v. 11, no 22, 2018. Disponível em: http://www.revistas.udesc.br/index.php/modapalavra/article/view/ 11824. Acesso em: 20 jul. 2020. 
LEAN ENTERPRISE INSTITUTE, (Comp.). Léxico Lean: glossário ilustrado para praticantes do Pensamento Lean. 2. ed. São Paulo: LEAN INSTITUTE BRASIL, 2007.

MAIOLI, F. M; PRESOTTO, J; PALMA, C. Coolhunting: Métodos e Práticas/ Maioli, Presotto \& palma: Milão, 2012.

MARCONI, M. de A; LAKATOS, E. M. Fundamentos de Metodologia Científica. $8^{\circ}$ ed. São Paulo: Atlas, 2017.

OSTERWALDER, A; PIGNEUR, Y. Business Model Generation: inovação em modelos de negócios. Atlas Books, 2010.

RAYMOND, M. Tendencias: que son, como identificarlas, en qué fijarnos, cómo leerlas. London: Promopress, 2010.

RECH, S. R.; CARDIM, V.C. O Processo da Pesquisa Qualitativa na Investigação de Tendências. In: Pesquisas em design, gestão e tecnologia de Têxtil e Moda./ Organizadores, Isabel Cristina Italiano ... [et al.] - São Paulo: EACH/USP, 2016.

RECH, S. R. Estudos do Futuro \& Moda: uma abordagem conceitual. ModaPalavra e-Periódico. v.6, n.11, p.93-100. jul-dez 2013. Disponível em: http://www.revistas.udesc.br/index.php/modapalavra/article/view/ 3477. Acesso em: 30 jul. 2020.

RECH, S. R; GOMES, N. P. Anatomia das tendências e o desenvolvimento de produtos de moda. In: $\mathbf{1 2}^{\circ}$ Colóquio de Moda - $9^{\circ}$ Edição Internacional - $3^{\circ}$ Congresso de Iniciação Científica em Design de Moda, 2016.2 Disponível em: http://www.coloquiomoda.com.br/anais/Coloquio\%20de\%20Moda \%20-\%202016/GT/GT04-DESIGN-E-PROCESSOS-DE-PRODUCAOEM-MODA/GT-04_ANATOMIA-DAS-TENDENCIAS.pdf. Acesso em: 30 jul. 2020.

RECH, S. R; SILVEIRA, I. Abordagem terminológica dos estudos de tendências. Anais... $13^{\circ}$ Colóquio de Moda- UNESP Bauru, São Paulo, 2017. Disponível em: https://www.academia.edu/35337128/ABORDAGEM_TERMINOL\%C 3\%93GICA_DOS_ESTUDOS_DE_TEND\%C3\%8ANCIAS. Acesso em: 14 jun. 2020.

SANCHES, M. C. F. Moda e projeto: estratégias metodológicas em Design. São Paulo: Estação das letras e Cores, 2017.

SANTOS, J. Sobre tendências e o espírito do tempo. São Paulo: Estação das Letras e Cores, 2017.

SILVEIRA, I. Procedimentos metodológicos de pesquisa: ciência e conhecimento. Florianópolis: 2018. (Apostila do Programa de Pós-Graduação em Moda, Mestrado Profissional em Design de Vestuário e Moda, PPGMODA/UDESC).

SeIVeWright, S. Pesquisa e design. Porto Alegre: Bookman, 2009.

TEZEL, A: KOSKELA, L; TZORTZOPULOS, P. The functions of Visual Management. Salford, UK: International Research Symposium. 2009. 
TEIXEIRA, J. M. Gestão visual de projetos: Um modelo que utiliza o design para promover maior visualização ao processo de desenvolvimento de projetos. 2015. 330p. Proposta de Tese (Doutorado em Engenharia de Produção). Programa de PósGraduação em Engenharia de Produção, UFSC. Florianópolis, 2015. Disponível em: https://repositorio.ufsc.br/xmlui/handle/123456789/132982. Acesso em 30 jul. 2020.

TEIXEIRA, J. M. Gestão visual de projetos: utilizando a informação para inovar/ Júlio Monteiro Teixeira. - Rio de Janeiro: Atlas Books, 2018.

TEIXEIRA, J; SCHOENARDIE R.; MERINO, E.. Design Management: management levels and project development relations. In: Proceedings. Design Management: Toward a new era of innovation, Hong Kong, 2011, p. 194-201.

TEZEL, A.; KOSKELA, L.; TZORTZOPULOS, P. The functions of Visual Management. Salford, UK: International Research Symposium. 2009.

TRENDWATCHING. Luciana Stein. Online, 2018. Disponível em: https://trendwatching.com/pt/about/luciana/. Acesso em: 28 jul. 2020.

WEBB, A. The Signals are Talking: why today's fringe is tomorrow's mainstream. New York: PublicAffairs, 2016.

ZAMBERLAN, L. et al. Pesquisa em ciências sociais aplicadas/ org. Luciano Zamberlan. Ijuí: Ed. Unijuí, 2014. 